\section{GM roundup}

- Experiments at one of the remaining UK GM crops sites have been threatened not by protesters but by a tippling fox. The animal took a liking to the alcoholcontaining pitfall traps arranged around the site to catch insects. Its numerous drunken nighttime raids left researchers with fewer and fewer data points.

- But the most laid-back anti-GM protest yet has to be virtual crop destruction. A news release circulating late in July claimed that members of two action groups - the "LodiLoppers" and the "Cropatistas" — had destroyed about two acres of commercial plantings of GM corn somewhere near Lodi, a farming community in the fertile Central Valley of California. This vandalism was intended "to show the biotech industry. . .that these genetically engineered crops are not wanted in the US and that Californians will use any means necessary to eradicate this menace," the release stated. Well, any means, that is, bar actually doing something. According to one Lodi resident, there "is not one scintilla of truth" to the claim that any crops were damaged. He points out that the wanton destruction of several acres of corn is not something that would go unnoticed. Critics of biotechnology are wondering what's up, some puzzling over the secrecy and anonymity of this gesture, and others bewildered over what now seems to be a phantom incident.

- Commenting entirely rationally and soberly on a proposal to establish a single tightly controlled area within which UK trials on GM crops could take place, the director of an organic farming organization has compared GM crops with anthrax bacilli. Patrick Holden of the Soil Association said that the proposed area could become another "anthrax island" because "GM could cause contamination for a very long time." He did fail to mention that the seeds and DNA of organic crops are not equally long-lived, or that crops in general do not tend to cause fatal and infectious diseases in humans or animals. Other than that, the comparision is absolutely appropriate.

Business and Regulatory News Briefs written by Holger Breithaupt, Vicki Brower, Emma Dorey, Jeff Fox, John Hodgson, and Asako Saegusa.

\title{
Baby food makers to drop GM ingredients
}

Officials representing Novartis Consumer Health (Summit, NJ) said late in July that the company subsidiary that makes Gerber baby foods will no longer be using corn or soy derived from GM plants and, instead, is shifting toward use of "organic" ingredients in those products. Although a reexamination of Gerber baby food ingredients was triggered by an inquiry from an environmental activist at Greenpeace (New York), the company instituted its new policy based on an understanding of "what our customers want in baby food," according to a Gerber spokeswoman. "We're in the business of protecting our customers." The parent company also supports an active plant genetics research, development, and marketing program at another subsidiary, Novartis Seeds (Golden Valley, MN). However, Gerber executives were "operating independently" when they developed the policy not to use genetically "enhanced" ingredients, she says. Several other US-based baby food producers, including HJ Heinz (Pittsburgh, PA) and Healthy Time Natural Foods (Poway, CA), say that they are following similar policies.

\section{USDA aims at Africa}

Agriculture Secretary Dan Glickman announced in July that the US Department of Agriculture (USDA; Washington, DC) is initiating a scientific exchange program to enhance crop biotechnology research in sub-Saharan Africa. At the outset, the program will provide modest funding to encourage partnerships involving USDA; universities and colleges; the International Maize and Wheat Improvement Center (Texcoco, Mexico); and agricultural research institutions in Africa, such as the National Agricultural Research Service in Kenya, Ghana, and Senegal. In addition to improving key crops in Africa, where agriculture accounts for about one-third of all economic activity, USDA says the project will also promote "an awareness of the benefits of biotechnology for developing nations and ensure the crops produced this way are healthy and safe."

\section{Japan to label GMOs}

Japan is to introduce new regulations that stipulate mandatory labeling of 30 food products containing genetically modified organisms (GMOs), including soybeans, potatoes, and corn. According to the draft regulations, unveiled in August by the Ministry of Agriculture, Forestry and Fisheries (MAFF; Tokyo), products that contain more than $5 \%$ GMOs would be labeled accordingly, while foodstuffs that may contain GM ingredients (because of imports containing mixtures of GMOs and non-GMOs) would be labeled as "undifferentiated." But products such as soy sauce and cornflakes, which lose GM protein and DNA during the production process, would be exempt from such labeling. Japan- ese food companies are predicting a sharp increase in the price of products when the new rules come into effect in April 2001. They say that carrying out tests to detect GMOs in the product could increase costs by as much as $50 \%$, and that switching to domestically produced GM-free ingredients could double the original cost. Meanwhile, consumer groups say that labeling products as "undifferentiated" will confuse the public, and are calling for a stricter regulation to be applied on isolated handling of GM crops by exporters.

\section{It's the real thing}

After receiving complaints from various pressure groups, the UK Advertising Standards Authorities (ASA) — whose role is to ensure that advertisement are "legal, honest and truthful"- took Monsanto to task over a series of full-page press advertisements that aimed to communicate Monsanto's enthusiasm about plant biotechnology. The ASA upheld several complaints of a factual nature - that Monsanto had only been testing GM crops for 16 years and not 20 as implied in the ads. There were complaints, too, that the combining of text saying that GM crops had been approved in 20 countries (true) with pictures of GM tomatoes and potatoes (which exist) implied that GM potatoes and tomatoes had been approved in 20 countries (not true). A spokesman for the ASA commented that a large company like Monsanto should be aware that "there are groups out there who pick holes in everything it says and should be very careful with their advertising." Clearly, like many other large companies, Monsanto should stick to vacuous copy and tag-lines. Look out for "GM is it"; "GM: just do it"; "GM, because I'm worth it" or "Welcome to GM country." 